37. Soroka, Yu. M. (2015). Deportation of the Polish population from the territory of USSR. 1944-1946. Pomiędzy. PolonistycznoUkrainoznawcze Studia Naukowe, 1, pp. 57-67 (ukr).

38. Soroka, Yu. M. (2007). Population of West Ukrainian lands: deportation, resettlement, mobilization, migration (1939-1950's), Kyiv, 275 p. (ukr).

39. Soroka, Yu. M. (2013). Population of West-Ukrainian Lands: Ethnopolitical and Demographic Dimension, 1939-1950's, Kyiv, 415 p. (ukr).

40. Soroka, Yu. M. (2002). Ukrainian-Polish migration (1944-1946) in the modern Ukrainian historiography. Bulletin of Taras Shevchenko National University of Kyiv. History, 63-64, pp. 25-26 (ukr).

41. Sushchuk, O. P. (2009). Soviet punitive repressive system: 1944-1953 (based on Volhyn region materials). Candidate's thesis, Lutsk, 222 p. (ukr)

42. Tokarskyi, V. V. (2011). Political Repressions in the Western Regions of Ukraine in 1939-1941. Extended abstract of Candidate's thesis, Lutsk, 20 p. (ukr).

43. Shyshela, S. I. (2013). Transfer Ukrainian and Polish population 1944-1946 years. In modern historiography and sources. Historical Archives: Science studio, 11, pp. 146-152 (ukr).

(c) Довбня Ольга

Надійшла до редакції 17.01.2018

Удк 94+2-722:271/272(477.85/.87)

\title{
КЛАПЧУК ВОЛОДИМИР,
}

доктор історичних наук, завідувач кафедри готельно-ресторанної та курортної справи, Прикарпатський начіональний університет імені Василя Стефаника

\section{ТИМОФІЙ ОКСАНА,}

аспірант кафедри готельно-ресторанної та курортної справи, Прикарпатський начіональний університет імені Василя Стефаника

\section{ДУХОВЕНСТВО УГКЦ ПІВНІЧНО-ЗАХІДНОї ГУЦУЛЬЩИНИ У 1836-1935 pp.}

У статті вперше встановлено хронологію діяльності парохів Української греко-католицької церкви в північно-західній частині Гуцульщини (у межах сучасної Івано-Франківської області). На цій території діяло дев'ять парафій, що об'єднували близько 20 церков у 17 населених пунктах. Відомості про духовенство північно-західної частини Гуцульщини взяті 3 шематизмів, фондів Центрального державного історичного архіву України (Львів), приватного архіву родини Клапчуків у Делятині. Перші відомості про священиків відомі з середини XVII ст. Установлено, що впродовж століття в північно-західній частині Гуцульщини парохами було 74 священики (7-9 у кожному селі). Середній час праці на парафії у Білих Ославах, Красні, Ланчині, Саджавці та Яблуниці складав 11,1 року, у Заріччі - 12,5, а в Делятині, Дорі та Микуличині - 14,3 року. Понад 40 років парохами служили троє священиків, 30-40 років шестеро. Троє священиків служили парохами у двох парафіях.

Ключові слова: парох; парафрія; церква; Українська греко-католицька церква; Гуцульщина.

Постановка проблеми та стан її дослідження. Священики Української греко-католицької церкви відігравали визначальну роль у формуванні духовного, морального, культурного та просвітницького обличчя Гуцульщини. Більшість із них були представлені в культурно-освітніх, мистецькихі наукових громадських організаціях. Однак на сьогодні практично немає повних хронологічних рядів правління священиків парафій північно-західної частини Гуцульщини, що лежить у долині р. Прут. Це й спонукало авторів до встановлення якнайповнішої інформації з досліджуваного питання.

Тема діяльності УГКЦ на Гуцульщині детально вже висвітлювалася в публікаціях М.і В. Клапчуків [1] та Р. Про- цака [2]. Майже від середини XVIII ст. відомості про священиків зберігалися в найдавніших парафріяльних метриках досліджуваної території, однак у 1944-1950 pp. їх практично було знищено. При підготовці матеріалів використано 52 шематизми [3-6], матеріали Центрального державного історичного архіву України (Львів) [8], приватного архіву родини Клапчуків у Делятині [7].

Головною метою статті $€$ введення в науковий обіг нових матеріалів про духовенство північно-західної частини Гуцульщини 1836-1935 рр.

Виклад основного матеріалу. Найдавніші конкретні дані про священиків північно-західної Гуцульщини походять із середини XVII ст. Тоді в Делятині, з нагоди 
родинної війни між магнатами Белзецькими, у 16431645 pp. згадано священика Андрія Намісника, який з волі шляхти командував артилерією при облозі Делятинського замку. Навчений військової справи, у 1648 р. він очолив повстанський загін і з його допомогою розбив у Красній магната Яблонського, який утікав зі скарбами перед козацтвом Б. Хмельницького з Київщини до добре укріпленого Пнівського замку [1]

У 1836-1935 рр. парафої знаходилися в Білих Ославах, Делятині, Дорі, Заріччі, Красній, Ланчині, Микуличині, Саджавці та Яблуниці, до яких належали всі села долини р. Прут, за винятком Лоєвої, що належала до парафії в Надвірній, та Горішнього і Середнього Майданів, які належали до парафії в Глинках.

Білі Ослави. У 1836-1850 рр. парохом був М. Ґадзінський (тут і надалі в дужках: * - рік народження) (*1798). У 1841-1845 рр. його помічником згаданий С. Саврасевич, 1850 р. - І. Квочинський. Від 1853 р. спочатку завідувачем, а пізніше парохом став Е. Ґаздінський (*1824), який правив до 1894 р. 3 уваги на велику парафію, що охоплювала села Білі Ослави, Чорні Ослави, Чорний Потік, він мав помічників: до 1865 р. - І. Квочинського; 1865-1867 - Т. Бурачинського; 1868-1872 Б. Камінського; 1876-1878 - Л. Калинського; 1879 - Р. Левицького; 1880 - Е. Левицького; 1883 - В. Бурачинського; 1887-1894 - Д. Балицького. Останній у 1895-1896 рр. став адміністратором парафії. 1897 р. парохом назначено І. Городиського, який на тому становищі перебував до 1907 р. За їх служіння співробітниками були О. Решетилович (1895), О. Базилевич (1896-1900), А. Кордовський (1903-1906) і В. Кунинський (1907-1909). Після І. Городиського парохією завідували адміністратор К. Андрухович (1909) та М. Руденський (1910). 3 1912 р. парохом став А. Глодзінський $\left({ }^{*} 1861\right)$, але час його правління невідомий, оскільки під час Першої світової війни шематизми не видавалися. В останні передвоєнні роки співробітником пароха був М. Томич. У 1925-1932 рр. парохом працював М. Дурделло (“1864), співробітником - С. Сохацький (1930-1933). У 19331935 рр. адміністрування парафії здійснював Е. Сливинський, а співробітником у нього був Д. Юган (1935).

Делятин. У 1836-1850 рр. парохом був Д. Федорович (*1790). У 1853-1855 рр. його замінив адміністратор І. Билинкевич (*1825), а останнього - А. Витошинський (*1816), який був парохом у 1859-1891 рр. Відтак парафрією завідував адміністратор К. Мудрак (18921894), що поступився місцем М. Драгомирецькому (*1837), який був парохом у 1894-1914 рр. У 19251929 рр. парохом був Л. Порубальський (*1869). Після його вбивства, до 1933 р. парафрією завідував адміністратор 3. Золотий (*1897), який пізніше став парохом і на тому становищі був до 1944 p.

Дора. 1836 р. парохом згадувався І. Клішкевич (*1803), а після нього адміністратором (1839-1845) та парохом (1850-1861) став В. Левицький (*1810). Після його смерті до 1865 р. адміністратором парафії працював Т. Блонський (*1829), якого відтак назначено парохом. На тому становищі він був до 1897 р. 1900-1912 pр. парохом був Г. Громадка (*1836). У 1913 р. парафрією завідував адміністратор Р. Петровський. До 1827 р. парохом був М. Ганушевський (*1880), який після обрання послом до парламенту виїхав з Дори, а на його місце прибув Е. Шмерековський (*1864), який займав становище до 1940-х рр.

Заріччя. 1836-1861 рр. парохом був І. Блонський (*1874), а його на посаді адміністратора замінив В. Камінський (1864). У 1865-1872 рр. парохом згадувався Ю. Величковський (*1814), у 1876-1897 рр. - М. Волошин (*1828). У 1900-1925 рр. парохом був Д. Луговий
(*1842). Після нього парафією завідували адміністратори С. Сохацький (1927-1928) і М. Любович (1928). Відтак парохом став А. Дмитраш (1930-1935).

Красна. У 1836-1850 рр. парохом був І. Добрянський (*1804). 1853 р. адміністратором згадувався М. Чомкевич. У 1854-1855 рр. парохом був І. Лучаковський (*1801), якого заступив та знаходився на тій посаді в 1859-1865 рр. А. Ключенко (*1807). У 1867-1868 рр. парафрією завідував адміністратор К. Ждерковський. Відтак парохом став К. Ікалович (1872-1897). 1900 р. адміністратором згадувався І. Сіменович. Його заступив парох О. Лелет (*1856), який пробув у Красній до 1925 р. Від 1927 р. до післявоєнних років парохом Красної був А. Лакуста $\left({ }^{*} 1880\right)$.

Ланчин. У 1836-1872 рр. парохом був А. Федорович (*1796). Пізніше адміністраторами парафії були М. Фільварків (1876) та І. Білоус (1877-1878). У 1879-1880 рр. парохом працював О. Радзикевич $\left({ }^{*} 1828\right)$. Його замінив К. Букоємський (*1828), який на тій посаді працював кілька років, бо в 1887 р. парохом згаданий Д. Хомин. У 1889-1904 рр. правив І. Михалевич. 31905 до 1912 рр. парохом згадувався М. Левицький (*1835). При ньому співробітниками були М. Руденський (1905-1906), Т. Крохмалюк (1907-1911) та Б. Подолинський (1912). Від 1913 р., спочатку адміністратором, а потім і парохом був І. Латишевський (*1871). На цій посаді він знаходився до 1935 р.

Микуличин. 1836-1845 рр. парохом був К. Трибчинський (*1796). 3 уваги на велику площу села парох мав співробітників: І. Волянського (1836), В. Левицького (1839), С. Саврасевича (1841), І. Проскурницького (1844-1845). Останній 1850 р. згадувався адміністратором. У 1853-1854 рр. адміністратором був І. Крижановський. Від 1855 р. парафрією керував І. Герасимович (*1811). У нього співробітниками згадувалися О. Яворський (1859), П. Монастирський (1860), Д. Воєвідка (18611865), Д. Луговий (1872), М. Олексій (1876), А. Сумик (1877-1883) і І. Майковський (1877). Востаннє І. Герасимович згаданий парохом у 1877 р. У 1889 р. адміністратором був М. Єднакій. 1891-1913 р. парохом згадувався Т. Галайчук (*1850). Співробітниками в нього були С. Грицина (1891-1892), В. Попель (1893-1894), С. Билинкевич (1895-1908), Я. Марчак (1909), О. Карпінський і А. Наконечний (1911-1912). 1913 р. співробітником став М. Ганушевський. У 1925-1935 рр. парохом був О. Луців (*1877), а його співробітниками в 1930-1932 рр. був Д. Юган, у 1933-1935 рр. - М. Куницький.

Саджавка. У 1836-1844 рр. парохом був І. Тимінський (*1764). 1845 р. адміністратором парафрії згадувався А. Зарицький. У 1850-1864 рр. парохом був В. Целевич (*1793), 1865 р. - К. Глібовицький, 1867-1900 рр. Ю. Красицький (*1826). Після короткого часу адміністрування О. Базилевича (1903-1905) парохом став С. Бобикевич (*1859) і на тій посаді знаходився до смерті в 1932 р. 1933 р. парафію адміністрував В. Луцький, після чого парохом став М. Андріїшин (*1876).

яблуниця. У 1836-1841 рр. парохом був Г. Тулінський (*1785). Після короткого адміністрування С. Билинкевича (1844-1845) парохом став О. Глібовицький (*1810), який на тій посаді був у 1850-1891 рр. Останній у 1892 р. був адміністратором, а парохом став М. Недільський (*1835). На цій посаді він пробув до 1907 р. Його співробітником у 1907 р. був Д. Райт, який 1908 р. став адміністратором. 31909 до 1925 рр. правив С. Билинкевич (*1869). У 1927-1929 рр. парохом був В. Луцький (*1900), а з 1930 р. адміністратором став В. Фроляк.

Загалом, у дев'яти селах північно-західної частини Гуцульщини встановлено 74 парохи (табл. 1). 
Таблиця 1. - Парохи північно-західної частини Гуцульщини

\begin{tabular}{|c|c|c|c|c|}
\hline Рік & Білі Ослави & Делятин & Дора & Заріччя \\
\hline 1836 & \multirow{5}{*}{ М. Ґадзінський } & \multirow{5}{*}{ Д. Федорович } & І. Клішкевич & \multirow{9}{*}{ І. Блонський } \\
\hline 1837 & & & \multirow{8}{*}{ В. Левицький } & \\
\hline 1844 & & & & \\
\hline 1845 & & & & \\
\hline 1850 & & & & \\
\hline 1853 & \multirow{18}{*}{ Е. Ґадзінський } & \multirow{3}{*}{ І. Билинкевич } & & \\
\hline 1854 & & & & \\
\hline 1855 & & & & \\
\hline 1859 & & \multirow{12}{*}{ А. Витошинський } & & \\
\hline 1864 & & & \multirow{16}{*}{ Т. Блонський } & В. Камінський \\
\hline 1865 & & & & \\
\hline 1867 & & & & Ю. Величковський \\
\hline 1872 & & & & \\
\hline 1876 & & & & \multirow{12}{*}{ М. Волошин } \\
\hline 1877 & & & & \\
\hline 1879 & & & & \\
\hline 1883 & & & & \\
\hline 1887 & & & & \\
\hline 1889 & & & & \\
\hline 1891 & & & & \\
\hline 1892 & & \multirow{2}{*}{ К. Мудрак } & & \\
\hline 1893 & & & & \\
\hline 1894 & & & & \\
\hline 1895 & Д. Балицький & & & \\
\hline 1897 & \multirow{6}{*}{ І. Городиський } & & & \\
\hline 1900 & & & \multirow{8}{*}{ Г. Громадка } & \multirow{10}{*}{ Д. Луговий } \\
\hline 1903 & & & & \\
\hline 1905 & & М Ппагомипенций & & \\
\hline 1906 & & IVI. Драл Омиирецькии & & \\
\hline 1908 & & & & \\
\hline 1909 & К. Андрухович & & & \\
\hline 1910 & М. Руденський & & & \\
\hline 1912 & \multirow{2}{*}{ А. Глодзінський } & & & \\
\hline 1913 & & & Р. Петровський & \\
\hline 1925 & \multirow{5}{*}{ М. Дурделло } & \multirow{4}{*}{ Л. Порубальський } & \multirow{2}{*}{ М. Ганушевський } & \\
\hline 1927 & & & & \multirow{2}{*}{ С. Сохацький } \\
\hline 1928 & & & \multirow{5}{*}{ Е. Шмерековський } & \\
\hline 1929 & & & & М. Любович \\
\hline 1930 & & \multirow{3}{*}{ 3.Золотий } & & \multirow{3}{*}{ А. Дмитраш } \\
\hline 1933 & \multirow{2}{*}{ Е. Сливинський } & & & \\
\hline 1935 & & & & \\
\hline Paзом: & 9 & 7 & 7 & 8 \\
\hline
\end{tabular}

\begin{tabular}{|c|c|c|c|c|c|}
\hline Рік & Красна & Ланчин & Микуличин & Саджавка & Яблуниця \\
\hline 1836 & \multirow{4}{*}{ І. Добрянський } & \multirow{11}{*}{ А. Федорович } & \multirow{3}{*}{ К. Трибчинський } & \multirow{2}{*}{ І. Тимінський } & Г. Тулінський \\
\hline 1837 & & & & & \multirow{2}{*}{ С. Билинкевич } \\
\hline $\begin{array}{l}1044 \\
1845\end{array}$ & & & & А. Зарицький & \\
\hline 1850 & & & І. Проскурницький & \multirow{5}{*}{ В. Целевич } & \multirow{14}{*}{ О. Глібовицький } \\
\hline 1853 & М. Чомкевич & & 1. Крижановський & & \\
\hline 1854 & \multirow{2}{*}{ І. Лучаковський } & & \multirow{11}{*}{ І. Гарасимович } & & \\
\hline$\frac{1855}{1859}$ & & & & & \\
\hline 1864 & \multirow[t]{2}{*}{ А. Ключенко } & & & & \\
\hline 1865 & & & & К. Глібовицький & \\
\hline 1867 & К. Ждерковський & & & \multirow{14}{*}{ Ю. Красицький } & \\
\hline 1872 & \multirow{12}{*}{ К. Ікалович } & & & & \\
\hline 1876 & & М. Фільварків & & & \\
\hline 1877 & & І. Білоус & & & \\
\hline 1879 & & О. Радзикевич & & & \\
\hline 1883 & & К. Букоємський & & & \\
\hline 1887 & & Д. Хомин & & & \\
\hline $\begin{array}{l}1889 \\
1891\end{array}$ & & \multirow{7}{*}{ І. Михалевич } & М. Єднакій & & \\
\hline 1892 & & & \multirow{6}{*}{ Т. Галайчук } & & Д. Хомин \\
\hline 1893 & & & & & \multirow{5}{*}{ М. Недільський } \\
\hline 1894 & & & & & \\
\hline 1895 & & & & & \\
\hline $\begin{array}{l}1897 \\
1900\end{array}$ & & & & & \\
\hline & 1. СINIEHOВИЧ & & & & \\
\hline
\end{tabular}


Продовження табл. 1

\begin{tabular}{|c|c|c|c|c|c|}
\hline Рік & Красна & Ланчин & Микуличин & Саджавка & Яблуниця \\
\hline 1903 & \multirow{9}{*}{ О. Лелет } & І. Михалевич & \multirow{8}{*}{ Т. Галайчук } & \multirow{2}{*}{ О. Базилевич } & \multirow{3}{*}{ М. Недільський } \\
\hline 1905 & & \multirow{6}{*}{ М. Левицький } & & & \\
\hline 1906 & & & & \multirow{11}{*}{ С. Бобикевич } & \\
\hline 1908 & & & & & Д. Райт \\
\hline 1909 & & & & & \multirow{8}{*}{ С. Билинкевич } \\
\hline 1910 & & & & & \\
\hline 1912 & & & & & \\
\hline 1913 & & \multirow{8}{*}{ І. Лятишевський } & & & \\
\hline 1925 & & & \multirow{7}{*}{ О. Луців } & & \\
\hline 1927 & \multirow{6}{*}{ А. Лакуста } & & & & \\
\hline 1928 & & & & & \\
\hline 1929 & & & & & \\
\hline 1930 & & & & & \\
\hline 1933 & & & & В. Луцький & В. Фроляк \\
\hline 1935 & & & & М. Андріїшин & \\
\hline Разом: & 9 & 9 & 7 & 9 & 9 \\
\hline
\end{tabular}

\section{Висновки}

Установлено, що впродовж століття в дев'яти селах північно-західної частини Гуцульщини парохами було 74 священики (7-9 у кожному селі). Середній час роботи на парафії в Білих Ославах, Красні, Ланчині, Саджавці та Яблуниці складав 11,1 року, у Заріччі - 12,5, а в Делятині, Дорі та Микуличині - 14,3 року. Найдовше парохами працювали О. Глібовицький (Яблуниця, 43 р.), Е. Ґадзінський (Білі Ослави, 43 р.), А. Федорович (Ланчин, 41 р.), Т. Блонський (Дора, 37 р.), Ю. Красицький (Саджавка, 37 р.), І. Гарасимович і Т. Галайчук (обидва - Микуличин, 35 р.), А. Витошинський (Делятин, 34 р.), М. Драгомирецький (Делятин, 32 р.).

Із загальної кількості священиків лише троє служили парохами у двох парафріях: Д. Хомин (Ланчин, Яблуниця), В. Луцький (Яблуниця, Саджавка) та І. Билинкевич (Яблуниця, Делятин).

Таким чином, використовуючи метод історичної хронології, ми виконали важливе для регіональної історії Гуцульщини завдання - установили імена й дати діяльності священиків дев'яти парафрій, що знаходилися в територіальних межах сучасної Івано-Франківської області. Ці особи важливі не тільки для релігійної історії Франківщини, оскільки їхні настанови та повчання формували майже століття світогляд та духовні підвалини жителів нашого краю, але й для тих, розкиданих по всьому світу українців, які намагаються зрозуміти, хто вони i звідки їхнє коріння.

\section{ЛІТЕРАТУРА}

1. Клапчук В. М., Клапчук М. М. Делятинщина: історикогеографрічне дослідження. Делятин, Івано-Франківськ: Фоліант, 2007. С. 512-520.

2. Процак Р. Церкви Прикарпатського краю. Івано-Франківськ: Лілея-НВ, 2006. С. 104-115.

3. Шематизмъ всего клира греко-католицкой Епархіи Станиславовской на рокъ Божій 1889, 1891-1898, 1900, 19031909, 1911-1912.

4. Шематизм всего кліра греко-католицкої епархії Станиславівської на рік Божий 1913, 1925, 1927-1931 і 1935.

5. Schematismus Archidioeceseos ritu graeco-catholici Leopolensis pro anno 1836, 1839, 1841, 1845, 1850, 1853-1855, 18591861, 1864, 1865, 1867, 1868, 1872, 1877-1880, 1883.

6. Schematismus universi cleri graeco-catholicae dioeceseos Stanislaopolensis pro anno domini 1887, 1928, 1932 et 1933.

7. Приватний архів родини Клапчуків у Делятині, ф. 4, оп. 4 , спр. 2.

8. Центральний державний історичний архів України (Львів), ф. 17, оп. 1, спр. 131, арк. 552-553.

Клапчук Владимир,

доктор исторических наук, заведуюший кафедрой гостиннично-ресторанного и курортного дела, Прикарпатский национальный университет имени Васыля Стефаныка

Тимофий Оксана,

аспирант кафедры гостиннично-ресторанного и курортного дела,

Прикарпатский национальный университет имени Васыля Стефаныка

\section{ДУХОВЕНСТВО УГКЦ СЕВЕРО-ЗАПАДНОЙ ГУЦУЛЬЩИНЫ В 1836-1935 22.}

В статье впервые восстановлено хронологию деятельности настоятелей Украинской греко-католической церкви в северо-западной части Гуцульщины (в пределах современной Ивано-Франковской области). На этой территории существовало девять приходов, которые объединяли около 20 церквей в 17 населенных пунктах. Информация о духовенстве северо-западной части Гуцульщины почерпнута из шематизмов, фондов Центрального государственного исторического архива Украины (Львов), частного архива семьи Клапчуков в Делятине. Первые сведения о священниках известны с середины XVII в. Установлено, что на протяжении века в северно-западной части Гуцульщины настоятелями были 74 священника (7-9 в каждом селе). Длительность работы в приходе в Белых Ославах, Красной, Ланчине, Саджавке и Яблунице составляла 11,1 года, в Заречье - 12,5, в Делятине, Доре и Микуличине - 14,3 года. Более 40 лет настоятелями служили трое священников, 30-40 лет - шестеро. Трое священников служили настоятелями в двух приходах.

Ключевые слова: настоятель; приход; церковь; Украинская греко-католическая церковь; Гуцульщина. 
Klapchuk Volodymyr,

Doctor of Historical Sciences, Head of the Department of Hotel, Restaurant and Resort Business,

Vasyl Stefanyk Precarpathian National University

Tymofii Oksana,

research student of the Department of Hotel, Restaurant and Resort Business,

Vasyl Stefanyk Precarpathian National University

\section{THE CLERGY OF THE UKRAINIAN GREEK CATHOLIC CHURCH OF THE NORTHWESTERN PART OF HUTSUL REGION BETWEEN 1836 AND 1935}

The chronology of the activities of Ukrainian Greek Catholic pastors in the northwestern part of Hutsul region (within present-day Ivano-Frankivsk oblast) has been found out in the article. There were nine parishes on this territory. The above-mentioned parishes united about 20 churches in 17 settlements. Information on the clergy of the northwestern part of Hutsul region has been taken from schematisms, funds of the Central State Historical Archives of Ukraine (Lviv), and private archives of the Klapchuk family in Deliatyn. The first information on priests dates back to the middle of the XVIlth century. It has been found out that 74 priests (7-9 in each village) were pastors in the northwestern part of Hutsul region during the century. The average time of pastoral duties in Bili Oslavy, Krasna, Lanchyn, Sadzhavka and Yablunytsia was 11.1 years, in Zarichchia - 12.5 years, and in Deliatyn, Dora and Mykulychyn - 14.3 years. Three priests had been pastors for more than $\mathbf{4 0}$ years: 0 . Hlibovytsky (Yablunytsia, 43 years), E. Gadzinsky (Bili Oslavy, 43 years), and A. Fedorovych (Lanchyn, 41 years). There were priests who had been pastors for more than 30 years - T. Blonsky (Dora, 37 years), Yu. Krasytsky (Sadzhavka, 37 years), I. Harasymovych and T. Galaichuk (Mykulychyn, 35 years), A. Vytoshynsky (Deliatyn, 34 years), and M. Drahomyretsky (Deliatyn, 32 years). Three priests were pastors in two parishes (D. Khomyn, V. Lutsky, I. Bylynkevych).

Thus, using the method of historical chronology, the authors of the article have solved a very important issue concerning the history of Hutsul region. They have found out the names of priests in nine parishes within presentday Ivano-Frankivsk oblast. The chronology of the activities of these priests has been studied as well. These pastors are important not only for the history of religion in Ivano-Frankivsk, but also for Ukrainians scattered all over the world and trying to understand their origin. The priests have been forming mental outlook and cultural wealth of local people for about a century.

Key words: pastor; parish; church; Ukrainian Greek Catholic Church; Hutsul region.

\section{REFERENCES}

1. Klapchuk, V.M. and Klapchuk, M.M., 2007. Delyatinschina: historical and geographical research, Delyatin, Folio, Ivano-Frankivsk, p. $512-520$ (ukr).

2. Protsak, R., 2006. Church of the Carpathian Region. Lilia-HB, Ivano-Frankivsk, p. 104-115 (ukr).

3. List of clerics: Shematyzm vseho klyra hreko-katolytskoy Eparkhiy Stanyslavovskoy na rik Bozhiy 1889, 1891-1898, 1900, 19031909, 1911-1912.

4. List of clerics: Shematyzm vseho klyra hreko-katolytskoy Eparkhiy Stanyslavovskoy na rik Bozhiy 1913, 1925, 1927-1931 i 1935.

5. Schematismus Archidioeceseos ritu graeco-catholici Leopolensis pro anno 1836, 1839, 1841, 1845, 1850, 1853-1855, 18591861, 1864, 1865, 1867, 1868, 1872, 1877-1880, 1883.

6. Schematismus universi cleri graeco-catholicae dioeceseos Stanislaopolensis pro anno domini 1887, 1928, 1932 et 1933.

7. Private archive of the Klapchuk family in Delyatyn, fond 4, opys 4, sprava 2.

8. Central State Historical Archive of Ukraine (Lviv), fond 17, opys 1, sprava 131, arc. 552-553.

() Клапчук Володимир, Тимофрій Оксана

Надійшла до редакції 08.01.2018 